\title{
Consequences of increased deer browsing winter on silver fir and spruce regeneration in the Southern Vosges mountains: Implications for forest management
}

\author{
Patricia HEUZE* ${ }^{a *}$ Annik SCHNITZLER ${ }^{\mathrm{a}}$, François KLEIN ${ }^{\mathrm{b}}$ \\ a Laboratoire Biodiversité et Fonctionnement des écosystèmes, Équipe de Phytoécologie, Université de Metz, Campus Bridoux, \\ avenue du Général Delestraint, 57070 Metz Cedex, France \\ b Office National de la Chasse et de la Faune Sauvage, Centre National d'Étude et de Recherche Appliquée Sanglier-Cervidés, \\ 1 place Exelmans, 55000 Bar-le-Duc, France
}

(Received 19 February 2004; accepted 19 May 2004)

\begin{abstract}
Forest and wildlife management practices in the Vosges have changed rapidly during the last 200 years, modifying interactions between animals and plants, especially deer and silver fir. In order to assess the impact of browsing on fir regeneration, we compared two sets of similar forests which differed primarily in terms of deer population dynamics and history. On slopes with southern exposures, many fir seedlings did not reach heights above $30 \mathrm{~cm}$ and spruce developed; this was related to browsing intensity. Spruce expansion was also facilitated by its presence in nearby mature stands, and was not related to a particularly high level of browsing. Of the six site characteristics taken into consideration, only the presence of foliage from the understorey above seedlings was found to benefit fir by limiting spruce development and reducing browsing intensity. Results are discussed in light of current and proposed management practices for silver fir-beech forests and their wildlife.
\end{abstract}

silver fir-beech forest / regeneration / browsing / deer / management

Résumé - Conséquences de l'augmentation de l'abroutissement hivernal par les cerfs et chevreuils sur la régénération du sapin et de l'épicéa dans les Vosges du Sud. Implications pour la gestion forestière. Les récents changements de gestion forestière et faunistique ont profondément modifié les interactions entre la flore et la faune, notamment entre les cervidés et le sapin. Pour évaluer l'impact de l'abroutissement sur la régénération du sapin, nous avons comparé deux ensembles de forêts sur la base de conditions environnementales similaires mais à différents degrés de colonisation par les cervidés. Les résultats montrent que les sapins des versants exposés sud subissent une pression d'abroutissement forte et poussent difficilement au-delà de $30 \mathrm{~cm}$, alors que l'épicéa est particulièrement abondant. L'expansion de l'épicéa au détriment du sapin abrouti est également facilitée par sa présence parmi les arbres matures, mais ici sans relation avec un abroutissement particulièrement fort du sapin. Un seul facteur parmi les sept étudiés joue en faveur du sapin : la présence d'une strate arbustive, qui limite le développement de l'épicéa et réduit l'abroutissement du sapin. Les résultats sont discutés en relation avec la gestion actuelle des hêtraie-sapinières vosgiennes et de leur faune, et des propositions sont émises pour une gestion qui intègre davantage la présence des animaux.

hêtraie-sapinière / régénération / abroutissement / cervidés / gestion

\section{INTRODUCTION}

As in many other places in Europe, forests in the Vosges mountains of France have undergone rapid changes over the last 200 years. Native deciduous trees in silver fir-beech forests were replaced by a few species of conifers, primarily Norway spruce, resulting in the transformation of broad areas of natural forest communities into artificial coniferous stands [25, 52]. Since the 15th century wildlife management have contributed to the extinction of large carnivores (bears, lynx and wolves), and more recently, to the rapid rise in ungulate populations [28, 53]. These changes in forest and wildlife management modified the interactions between plants and animals, especially between deer (Cervus elaphus and Capreolus capreolus) and silver fir (Abies alba). Indeed, it would seem that increased browsing of silver fir by deer - which occurs mainly from November to April in the Vosges [29] - is leading to a replacement of the firs by spruce (Picea abies) which is not browsed heavily. Large herbivores may have a significant influence on the composition of forest regeneration [17, 18, 42], in relation with silvicultural methods $[26,27,35,44]$ and many other biotic and abiotic factors $[8,16,21,24,46]$. To assess the extent to which browsing may affect regeneration composition, we chose to focus on a limited number of site characteristics which influence fir and spruce seedling development, and the way deer select areas for shelter and foraging in winter. Roe deer and Red deer are usually

* Corresponding author: heuze@ hotmail.com 
attracted to sites which are warm and where vegetation is accessible (i.e. covered by less snow) or abundant, such as sunny patches, low elevations, and dense understories [34, 41, 46, 49, $54,55]$. At these desirable spots, browsing on seedlings is likely to be intense unless enough alternative food is available [13]. In our study, orientation, elevation, understorey density, and ground flora species, were each taken into account for their potential attractiveness to deer. The growth-rates of fir and spruce seedlings may also be linked to exposure and understorey density which influence light conditions, in the same way that logging which reduces overstorey density. Logging records were therefore added in the analysis. Lastly, fir seeds are little dispersed [57] and the abundance of fir in the mature stand nearby is critical in compensating for the potential mortality of seedlings due to browsing. Therefore, stand composition was considered as an additional site factor affecting the substitution of fir by spruce.

The aim of the study was to assess whether there is a substitution of fir by spruce in the regeneration due to browsing, and to specify the role of six related site characteristics (orientation, elevation, ground flora palatability, understorey density, cutting, and composition of the mature stand) likely to be involved.

\section{MATERIALS AND METHODS}

\subsection{Study area}

The Vosges mountains are located in North-eastern France, and reach an elevation of 1424 metres at their highest point. The research was carried out in the southern part of the Vosges where the principal soil type is an acidic brown earth on Hercynian granites. The climate is temperate. Mean annual precipitation ranges from 1000 to $2000 \mathrm{~mm}$. Average annual temperatures vary from $4{ }^{\circ} \mathrm{C}$ at $1200 \mathrm{~m}$ to $8{ }^{\circ} \mathrm{C}$ at $400 \mathrm{~m}$, and snow is frequent on the summits during the period from November to April. The major forest communities between 500 and $950 \mathrm{~m}$ are silver fir-beech stands (Luzulo luzuloidis-Fagetum sylvaticae, Fagion sylvaticae) [39]. Due to management practices carried out since the 19th century, conifers now dominate and Fagus sylvatica has been replaced to a large extent by Picea abies, and most forests exhibit an even-aged structure.

Two study sites were selected within a single $760 \mathrm{~km}^{2}$ area in the natural silver fir-beech forest range. Study forests of Site 1 and 2 consist of 30 to $50 \%$ spruce, 30 to $60 \%$ fir and 0 to $30 \%$ beech. At Site 1, the small populations of Roe deer (Capreolus capreolus) and Red deer (Cervus elaphus) did not affect the development of regenerating firs. It includes stands from the forests of Rupt-sur-Moselle, Thiéfosse and Le Thillot. Site 2, situated at about $30 \mathrm{~km}$ from Site 1, includes the forests of Vologne, Anould, Fraize and Plainfaing. The Red deer population started to increase in the early 1960's following the creation of the "Belbriette" game reserve and subsequent colonisation of adjacent forests, including those in Site 2, by some reserve animals. The population density inside the reserve was estimated thanks to nightcounting at 4.5 Red deer per 100 ha in the early 1980's, 13 in 1995, and 7 in 2000 . Forest and game managers agree that the carrying capacity for Red deer in these forests is 2 to 3 Red deer per $100 \mathrm{ha}$. The population of Roe deer decreased as the Red deer population rose, and the estimated 5 Roe deer per 100 ha in the early 1980's dropped to only 1.7 to 1.9 between 1995 and 2000. In about 1990, foresters at Site 2 observed a lack of fir seedlings resulting from browsing by deer, correlated with an increase in naturally-regenerating spruce. Nevertheless, the simultaneous presence of Roe and Red deer for decades prior to the present-day abundance in the latter species precludes a clear differentiation in the role of each species.

\subsection{Sampling and data collection}

Study compartments were first selected, based on Forest Department data, to satisfy the following criteria: (1) elevation ranging from 600 to $900 \mathrm{~m}$ with all four cardinal exposures represented; (2) evenaged stand at least 90 years of age and composed of more than $70 \%$ fir or spruce, or mixed fir/spruce; (3) vegetation mainly composed of Vaccinium myrtillus L., Deschampsia flexuosa L. or Luzula sp.; (4) restocking by natural regeneration of fir and spruce with no forestry intervention since its establishment, such as clearing, chemical treatment or removal of understorey; (5) silviculture based on shelterwood cuttings every 6 to 12 years in the regeneration phase (based on Forest Department data regarding the exact date of cutting).

At Site 1, 18 study compartments were situated on an area of 1900-ha. In each compartment, study plots were sampled on transects running along the hillside every $50 \mathrm{~m}$ in elevation, with a 200 meters distance between plots. Plots were actually studied when fir and/or spruce seedlings were present and the more abundant species, so that a total of 93 plots, each $16 \mathrm{~m}^{2}$ in size, was sampled in Summer 1999. Using the same method at Site 2, 202 plots were spread in 41 compartments located over a 2700-ha area: these were sampled in Summer 2000. In each plot of both sites, all seedlings under $150 \mathrm{~cm}$ were measured and their species noted (fir, spruce, or other). To assess the role of browsing on a possible substitution of fir by spruce, the number of browsing marks on the principal stem (from 0 to more than 6 marks) was recorded for every silver fir seedling at Site 2. A part of the seedlings under $10 \mathrm{~cm}$ may have been browsed shortly after germination with no visible sign of damage, and another part may have disappear [36, 40]. These outcomes of browsing could not be registered. To allow for statistical treatment (see Sect. 2.3), seedlings were grouped into four different height classes according to Saint-Andrieux et al. [48]: 0-9 cm seedlings, browsed by Roe deer and often up-rooted; $10-30 \mathrm{~cm}$ seedlings, foraged by both Roe and Red deer; 31-70 cm, seedlings browsed mainly by Red deer; and 71-150 cm, seedlings eaten only by Red deer. The dominant ground flora species was noted, orientation was determined using a compass, and the local stand composition arrived at by counting the trees of each species within a circle $45-\mathrm{m}$ in diameter around the plot. Understorey density in the areas surrounding regeneration was estimated using the distance of the furthest trees trunks an observer was able to see through the understorey when looking up slope, down slope, and to the left and right of the transect. Four density levels were defined: (1) high: observer not able to see further than $10 \mathrm{~m}$ in any direction; (2) medium-high: observer could see beyond $10 \mathrm{~m}$ in two or three directions, but small trees or shrubs blocked mature tree trunks; (3) medium-low: mature trees trunks sighted in 2 or 3 directions; (4) low: trunks seen in all four directions. The understorey at the local scale was also taken into consideration. For this purpose, the percentage of the plot surface covered by foliage from either small trees, shrubs, seedlings more than $1.5 \mathrm{~m}$ tall, or low branches of higher trees, was evaluated by the observer.

\subsection{Statistical analysis}

The aim of the analysis was to build a reference model, linking types of regeneration to site characterictics, with data from Site 1 (i.e. unaffected by deer browsing), for comparison with Site 2 (i.e. affected by deer browsing). For that purpose, data from each site were analysed separately using the same statistical procedure.

\subsubsection{Types of regeneration}

Correspondence analysis and hierarchical classification were used in order to group the plots which exhibited the same distribution (number of seedlings) of the three species into four height classes [32]. To organise the data set around independent axes, correspondence 
Table I. Types of regeneration. Percentage of seedlings according to species. Other species are broadleaves, mainly Fagus sylvatica, Acer pseudoplatanus, Fraxinus excelsior and Sorbus aucuparia. Regeneration dominated by silver fir was divided into three types according to the distribution $(\%)$ of the fir seedlings in four height classes.

\begin{tabular}{|c|c|c|c|c|c|c|c|c|c|}
\hline \multirow{2}{*}{ Site } & \multirow{2}{*}{ Regeneration } & \multirow{2}{*}{$n$} & \multicolumn{3}{|c|}{ Species } & \multicolumn{4}{|c|}{ Height classes $(\mathrm{cm})$} \\
\hline & & & Spruce & Fir & Others & $<10$ & $10-30$ & $31-70$ & $71-150$ \\
\hline 1 & fir $<30 \mathrm{~cm}$ & 26 & 9 & 73 & 18 & 51 & 36 & 10 & 3 \\
\hline 1 & fir $10-70 \mathrm{~cm}$ & 28 & 9 & 84 & 7 & 12 & 49 & 31 & 9 \\
\hline 1 & fir $>30 \mathrm{~cm}$ & 22 & 4 & 81 & 15 & 9 & 11 & 30 & 50 \\
\hline 1 & spruce & 8 & 80 & 10 & 10 & & & & \\
\hline 1 & fir-spruce & 9 & 54 & 31 & 15 & & & & \\
\hline 2 & fir $<30 \mathrm{~cm}$ & 61 & 14 & 79 & 7 & 46 & 36 & 14 & 4 \\
\hline 2 & fir $10-70 \mathrm{~cm}$ & 38 & 11 & 80 & 9 & 12 & 33 & 39 & 15 \\
\hline 2 & fir $>30 \mathrm{~cm}$ & 18 & 14 & 77 & 9 & 11 & 10 & 30 & 49 \\
\hline 2 & spruce & 49 & 74 & 22 & 4 & & & & \\
\hline 2 & fir-spruce & 36 & 57 & 37 & 6 & & & & \\
\hline
\end{tabular}

analysis was performed on tables composed of 12 column (4 height classes $\times 3$ species) and 93 (Site 1) or 202 (Site 2) lines. In order to identify types of regeneration, the coordinates of plots on the first axis (explaining up to $80 \%$ of the variation) were then analysed in the hierarchical classification, using Euclidian distances measurement and the Ward method of aggregation.

\subsubsection{Browsing levels}

To define browsing intensities, the number of fir seedlings per plot with $0,1,2,3,4,5,6$ or more browsing marks in each height class (28-column table), was also analysed using correspondence analysis and hierarchical classification.

\subsubsection{Regeneration, browsing, and site characteristics}

Chi-square was used to test the distribution homogeneity of regeneration types of each site for the various modalities of site descriptors and of browsing level. For quantitative data (time of last felling, elevation and percentage of understorey covering the plot), a discriminant analysis using Chi-square and the CART method (Classification And Regression Trees $[6,45]$ ) was performed to define the threshold values where observed distribution varied significantly from theoretical distribution.

\section{RESULTS}

\subsection{Regeneration typology}

At each site, five types of regeneration were defined (Tab. I). Three were dominated by fir seedlings, grouping the plots where firs were more numerous in the $<10 \mathrm{~cm}$ and $10-30 \mathrm{~cm}$ height classes: type fir $<30 \mathrm{~cm}$, the $10-30 \mathrm{~cm}$ and $31-70 \mathrm{~cm}$ classes: fir $10-70 \mathrm{~cm}$, the $31-70 \mathrm{~cm}$ and $71-150 \mathrm{~cm}$ classes: fir $>30 \mathrm{~cm}$. For the spruce type, spruce was clearly dominant as it represented $80 \%$ of the seedlings at Site 1 and $74 \%$ at Site 2. The fir-spruce type describes a mixture of the two species in all classes, spruce being slightly more numerous as it repre- sented more than $50 \%$ of the seedlings. Spruce and fir-spruce types were observed more frequently at Site $2(24.3 \%$ and $17.8 \%$ of the sample versus $8.6 \%$ and $9.7 \%$ at Site 1) whereas fir dominance was less frequent especially among the tallest seedlings (type fir $>30 \mathrm{~cm}$ : $8.9 \%$ at Site 2 versus $23.7 \%$ at Site 1).

\subsection{Browsing levels in site 2}

Three silver fir browsing levels were defined. At the lowest level (Bl), all seedlings show no or one browsing mark. At the intermediate level (Bm) up to $50 \%$ of the seedlings taller than $10 \mathrm{~cm}$ show 2 or 3 marks (seedlings under $10 \mathrm{~cm}$ were rarely marked). At the highest level (Bh), more than $50 \%$ of the seedlings taller than $10 \mathrm{~cm}$ show from 2 to more than 6 marks.

To analyse the role of browsing in regeneration differences between sites, the plots where fir was not the more abundant species (i.e. the spruce and the fir-spruce types) and exhibited the lowest level of browsing (Bl) were separated from the plots showing medium and high levels. As no fir had significant browsing in these types: "spruce Bl" and "fir-spruce Bl", the non-dominance of fir may not have been caused by foraging deer. On the other hand, in places that were often used for foraging, heavily-browsed seedlings could have been destroyed and browsing levels thus inaccurately evaluated as being low. But such areas would be expected to contain at least a few live seedlings with two or more browsing marks, corresponding to the Bm level. Therefore, when browsing level was medium or high, fir may have been replaced by spruce as a consequence of browsing. When silver fir remained the more abundant species (fir types) the data were not separated according to browsing level.

\subsection{Regeneration and site characteristics}

Relationships between the types of regeneration and environmental factors at Sites 1 and 2 are presented in Tables II and III. 
Table II. Relationships between regeneration and site characteristics at Site 1.

\begin{tabular}{|c|c|c|c|c|c|c|c|}
\hline \multirow[b]{2}{*}{ Regeneration } & \multicolumn{7}{|c|}{ Site characteristics } \\
\hline & Elevation & Exposure & $\begin{array}{c}\text { Stand } \\
\text { composition }\end{array}$ & $\begin{array}{c}\text { Ground } \\
\text { flora }\end{array}$ & $\begin{array}{l}\text { Understorey } \\
\text { density }\end{array}$ & $\begin{array}{c}\text { Understorey } \\
\text { corering seedlings }\end{array}$ & $\begin{array}{c}\text { Time of the } \\
\text { last cut }\end{array}$ \\
\hline fir $<30 \mathrm{~cm}$ & NS & NS & & NS & NS & NS & NS \\
\hline fir $10-70 \mathrm{~cm}$ & NS & NS & fir $* * *(1)$ & NS & NS & NS & NS \\
\hline $\mathrm{fir}>30 \mathrm{~cm}$ & NS & NS & & NS & NS & $>22 \% * * *$ & NS \\
\hline spruce & NS & NS & spruce $^{* * *}$ & NS & NS & NS & NS \\
\hline fir-spruce & NS & NS & $\operatorname{mixed}^{* * *}$ & NS & NS & NS & NS \\
\hline
\end{tabular}

Chi-square test: $* * * p<0.01$. NS: not significant. A significant difference indicates that the type of regeneration was more often observed in the condition that is mentioned. As spruce and fir-spruce type were poorly sampled, the test was also run with the two data sets together. (1): Chi-square compares the distribution of the three types of fir regeneration with the rest of the regeneration.

Table III. Relationships between regeneration and site characteristics at Site 2.

\begin{tabular}{|c|c|c|c|c|c|c|c|}
\hline \multirow[b]{2}{*}{ Regeneration } & \multicolumn{7}{|c|}{ Site characteristics } \\
\hline & Elevation & Exposure & $\begin{array}{c}\text { Stand } \\
\text { composition }\end{array}$ & $\begin{array}{l}\text { Ground } \\
\text { flora }\end{array}$ & $\begin{array}{c}\text { Understorey } \\
\text { density }\end{array}$ & $\begin{array}{c}\text { Understorey } \\
\text { corering seedlings }\end{array}$ & $\begin{array}{l}\text { Time of the } \\
\text { last cut }\end{array}$ \\
\hline fir $<30 \mathrm{~cm}$ & NS & NS & & NS & NS & NS & NS \\
\hline fir $10-70 \mathrm{~cm}$ & NS & NS & fir***(1) & NS & NS & NS & NS \\
\hline $\mathrm{fir}>30 \mathrm{~cm}$ & NS & absent south* & & NS & NS & $>50 \% * * *$ & NS \\
\hline spruce Bl & NS & rare south* & NS & NS & NS & NS & NS \\
\hline fir-spruce Bl & NS & (2) & NS & NS & NS & NS & NS \\
\hline spruce $B m+h$ & NS & south* & spruce* & NS & NS & NS & NS \\
\hline fir-spruce $\mathrm{Bm}+\mathrm{h}$ & NS & (2) & $\operatorname{mixed}^{* *}(2)$ & NS & NS & NS & NS \\
\hline
\end{tabular}

Chi-square test: $* * * p<0.01, * * p<0.02, * p<0.05$. NS: not significant. A significant difference indicates that the type of regeneration is more often observed in the condition that is mentioned except when "rare" (i.e. the type was rarely observed in the mentioned condition) or "absent" (i.e. type never observed) is specified. Bl: Browsing low, Bm+h: Browsing medium + high. (1) Comparison of the distribution of the three types of fir regeneration with the rest of the regeneration. (2) Comparison of the distribution of the two Bl types with the two $\mathrm{Bm}+\mathrm{h}$ types. $N$ spruce $\mathrm{B} 1=20, n$ spruce $\mathrm{Bm}+\mathrm{h}=27$ (no fir was present in 2 of the 49 spruce type plots so they were not included in the sample), $n$ fir-spruce $\mathrm{Bl}=15, n$ fir-spruce $\mathrm{Bm}+\mathrm{h}=21$.

\subsubsection{Exposure}

Orientation to sun had no influence on the regeneration composition at Site 1 while it was important at Site 2. Here the South-facing slopes were characterised by a lack of tall fir seedlings, a rarity of spruce types with low levels of fir browsing, and an abundance of spruce regeneration containing browsed fir seedlings (Fig. 1). An analysis of the global level of browsing (grouping all types of regeneration) revealed that seedlings on South-facing slopes were browsed more intensively than those on slopes with other exposures $(\mathrm{Bl}+\mathrm{Bm}$ versus $\mathrm{Bh}$ : $\chi^{2}=5.31, \mathrm{df}=1, p=0.02$ ). Deer preferred to forage silver fir in sunny places in winter, an activity which favoured spruce regeneration.

\subsubsection{Mature stand composition}

At both sites, fir types were often observed when fir was also abundant in the mature stand nearby (more than $70 \%$ of the trees). Concerning spruce, a strong relationship was found at Site 1 as spruce type was associated with spruce stands, and fir-spruce type with mixed stands. However, at Site 2 such a relationship was not observed. Indeed, the types spruce $\mathrm{Bl}$ and fir-spruce

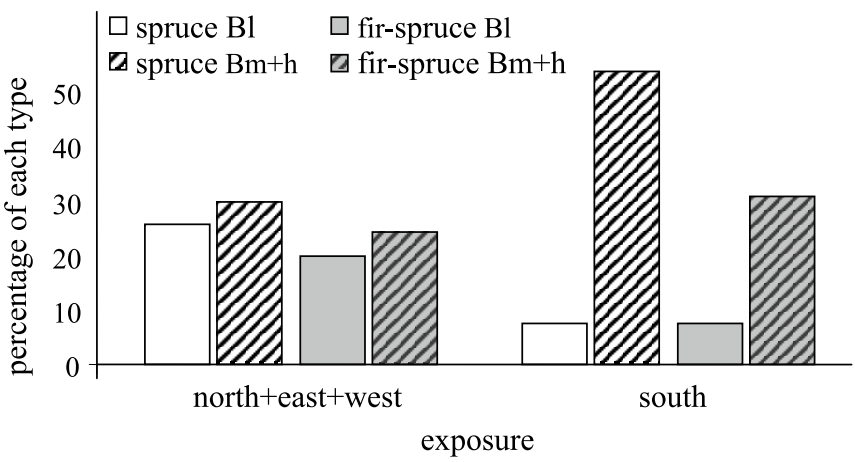

Figure 1. Abundance of spruce and fir-spruce types of regeneration as related to exposure at Site 2. Bl: lowest level of browsing, $\mathrm{Bm}+\mathrm{h}$ : medium and high level of browsing.

$\mathrm{Bl}$ were observed in the various conditions of stand composition, and the $\mathrm{Bm}+\mathrm{h}$ types were frequent both in the spruce and mixed stands (Fig. 2). Spruce seedlings at Site 2 were therefore more dispersed in the different adult stands compared with Site 1. 


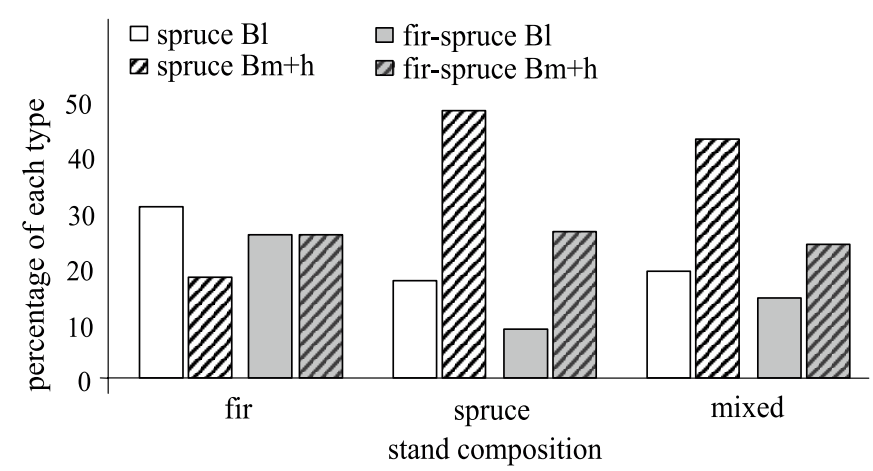

Figure 2. Abundance of spruce and fir-spruce types of regeneration as related to mature stand composition at Site 2. Bl: lowest level of browsing, Bm+h: medium and high level of browsing.

The analysis of the global level of browsing (grouping all types of regeneration) revealed that firs were browsed in a comparable way in all stand types, indicating that spruce was favoured by fir browsing only when it was already present in the mature stand. Thus, browsing intensity is of little importance in spruce relative abundance among seedlings when compared to the status of each species among the adult trees.

\subsubsection{Understorey}

At both sites, the density of the understorey surrounding regeneration had no significant relationship either to the composition or to the level of browsing. On the contrary, the analysis of the understorey just above the plot highlighted its importance at a more local scale. The dominance of fir seedlings taller than $30 \mathrm{~cm}$ was related to the presence of foliage covering at least $22 \%$ of the plot at Site 1 and $50 \%$ at Site 2 . Browsing of fir was low for half the plots with more than $50 \%$ covered, whereas it was medium or high in all plots with less than $50 \%$ covered $\left(\chi^{2}=5.52, \mathrm{df}=1, p<0.02\right)$. In addition, foliage above the regeneration prevented light from reaching seedlings, which may have put spruce at a disadvantage, as it is a more lightdependent species. Indeed, when foliage covered more than $50 \%$, spruce and fir-spruce types represented $20.7 \%$ of the regeneration and up to $44.8 \%$ when there was less cover $\left(\chi^{2}=4.34, \mathrm{df}=1, p<0.04\right)$

\subsubsection{Elevation, time of the last cut, and ground flora}

At both sites, the distribution of regeneration types was not related to elevation, and fir seedlings at the lowest elevations of Site 2 were not particularly browsed. There was no relationship found either between regeneration and the time of the last cut. On the other hand, there was a significant relationship between the species which dominated ground flora and the level of browsing: silver fir was less browsed when Vaccinium myrtillus $\mathrm{L}$. was abundant ( $\mathrm{B} 1$ versus $\mathrm{Bm}+\mathrm{h}: \chi^{2}=5.32, \mathrm{df}=1$, $p=0.02$ ). These differences in browsing intensity related to ground flora had no significant influence on the composition of regeneration.

\subsection{Interactions between site characteristics}

The modification of regeneration composition expected due to intense browsing when Vaccinium myrtillus was lacking may have been counterbalanced by another local characteristic, such as the absence of mature spruces nearby. Similarly, high browsing pressure may have been related more to the exposure or to poor coverage by understorey foliage. Interactions between the site characteristics were analysed using Chi-square and all possible combinations between significant modalities were tested. No significant relationship was found.

\section{DISCUSSION}

\subsection{How fir may be replaced by spruce or not}

In forests where deer populations are significant, spruce regeneration is particularly abundant and combined with a shortage of fir seedlings taller than $30 \mathrm{~cm}$. The question then is to what extent herbivores, and their foraging, are responsible.

Firstly, the replacement of fir by spruce can be a direct consequence of strong browsing pressure localised in highlyattractive places during winter, such as South-facing slopes. Repeated fir browsing favours spruce because it affects the establishment, growth and survival of browsed individuals. Browsing reduces foliage density, sometimes to the point of destroying entire individuals, thereby reducing competitiveness of browsed plants through limited apical growth and root development $[10,12,17,18,33,58]$. But browsing level differences are not necessarily related to a change in the abundance of fir and spruce seedlings, as shown by the absence of relation between regeneration and ground flora composition. Even so, the availability of alternative forage such as Vaccinium myrtillus determines deer foraging selectivity and influence on tree specific composition $[13,15,22,29]$. But, to come to a conclusion about the role of alternative foods in the mechanism of substitution, a more detailed study of vegetation would be necessary. Secondly, spruce can be given an advantage by local characteristics, such as the abundance of mature spruces in the stand, with no relationship to a particularly high browsing of fir.

The influence of browsing intensity and site characteristics may combine to either facilitate or slow fir replacement. When regeneration is widely covered by understorey foliage, fir can remain the more abundant species as a result of less browsing intensity and limited spruce regeneration. Welch et al. [59] observed that intense browsing of apical shoots of Picea sitchensis by Roe and Red deer was negatively correlated to the density of taller seedlings which produce sufficient lateral shoots for deer to feed on. Spruce requires more light for growth than fir and its competitiveness is held in check by a lack of light [4, $7,47,56]$, whereas fir exhibits better photosynthetic performance and grows faster $[2,19]$. But cover provided by understorey also has a positive effect beyond browsing pressure. The understorey reduces the risk of spring frosts which affect fir more than spruce $[1,3,50]$ and protects seedlings from over-exposure to sun and uprooting when soil is washed away during strong rains, two important causes of fir mortality [56]. In addition, by creating shade, understorey limits the development of herbaceous 
species such as Festuca altissima that may hinder fir establishment through allelopathic processes [5]. The composition of the understorey should be studied, as well as the role of broadleaves, in view of the importance of cover in the maintenance of fir, and because broadleaves should be more abundant than is currently the case in the silver fir-beech forest of the Vosges mountains. In fact, Fagus sylvatica regenerates easily and broad-leaved species such as ash Fraxinus excelsior, sycamore Acer pseudoplatanus, rowan Sorbus aucuparia, elm Ulmus glabra, elder Sambucus nigra, alpine elder Sambucus racemosa, holly Ilex aquifolium, can be found in the silver fir-beech forest range. According to Eiberle and Bucher [13], a reduction in silver fir browsing could be achieved by a higher supply of ash, sycamore and rowan. Guibert et al. [20] observed that an understorey containing broad-leaved species allows for the development of ground flora (but not its proliferation), thus improving the availability of alternative forage and limiting the risk of browsing on fir.

\subsection{Implications for forest management}

As fir is a slow-growing species it has poor resilience to browsing $[11,38]$, so its capability to survive and grow in shaded conditions (where it escapes heavy browsing) is a real advantage in the presence of deer. Nevertheless, in the presence of deer, foresters tend to clear out the understorey and carry out important fellings in order to increase light levels, therefore enhancing the growth of fir seedlings and reducing the browsing period (foresters, personal communication). In fact, such practices have the opposite effect and actually favour spruce. It is therefore imperative to stop planting this fast-growing, relatively unpalatable species; to create smaller gaps; and leave at least part of the existing cover intact during the regeneration phase. Small gaps benefit fir regeneration [9, 14, 19, 37], and when frequently repeated, support the understorey and ground vegetation layers [31]. In addition, it is important to achieve a proper balance between deciduous and coniferous species, not only to make the silver fir-beech forest more resistant to deer foraging, but also to many biotic and abiotic threats such as fungi or insect attack, wind, soil erosion or snow damage [30, $43,52]$.

The vegetation management suggested above implies important modifications in current, even-aged silviculture practices, and a move towards a management system more closely resembling nature. Nevertheless, the development of palatable broadleaved species, as well as the spreading of fir seedlings in several smaller gaps, may well be impeded by the presence of deer because dispersed regeneration is difficult to monitor. A temporary reduction in deer populations might therefore be necessary, and in some cases, a reduction in the impact deer have locally on a particularly sensitive area might be sufficient. Fir browsing could be reduced under locally high pressure from hunting for several years following silviculture practices, such as clearings, which are necessary to allow browsed seedlings to grow, but which also make regeneration more prone to browsing. Furthermore, the current expansion of the lynx and the programmed return of the wolf to the Vosges mountains will, in the long term, contribute to the regulation and the dispersion of deer populations, thereby lowering the impact on browsed species as observed by Hoskinson et al. [23] and
Singer et al. [51]. In any case, it is necessary to avoid additional feeding which sustains deer populations artificially.

\section{CONCLUSION}

We highlighted the role of a few site characteristics on the substitution or the maintenance of fir at the early stage of regeneration which is a very short period of time when compared with the time needed for a silver fir-beech stand to reach full renewal (100 to 150 years under a managed system and more than 300 years under natural conditions [30]). In the future it is necessary to study regeneration after browsing pressure is reduced (i.e. seedlings taller than $150 \mathrm{~cm}$ ) in order to confirm whether the site characteristics identified at the regeneration stage play a significant role over time, and can be used as a solid foundation for forestry management decision-making.

Acknowledgements: This study, part of P. Heuzé's Ph.D. thesis, was undertaken thanks to financial and technical support received from the French Office National de la Chasse et de la Faune Sauvage, Parc Naturel Régional des Ballons des Vosges, Direction Régionale de l'Environnement and Office National des Forêts.

\section{REFERENCES}

[1] Aussenac G., Étude des gelées tardives en relation avec les problèmes de reboisement, Ann. Sci. For. 30 (1973) 141-155.

[2] Aussenac G., Influences du couvert forestier sur la croissance de quelques résineux dans le jeune âge, Can. J. For. Res. 7 (1977) 8-18.

[3] Aussenac G., Interactions between forest stands and microclimate: ecophysiological aspects and consequences for silviculture, Ann. For. Sci. 57 (2000) 287-301.

[4] Aussenac G., Ducrey M., Étude de la croissance de quelques espèces forestières cultivées à différents niveau d'éclairement et d'alimentation hydrique, $106^{\mathrm{e}}$ Congrès des Sociétés Savantes, Nancy, 1 (1978) 105-117.

[5] Becker M., Bennett P., Propriétés allélopathiques d'une graminée forestière: la grande Fétuque (Festuca altissima), $6^{\mathrm{e}}$ Colloque International sur l'Écologie et la Biologie des Mauvaises Herbes, Comptes rendus COLUMA-EWRS 2 (1980) 451-460.

[6] Breiman L., Friedman J.H., Ohlsen R.A., Stone C.J., Classification and Regression Trees, Wadsworth \& Brooks, Monterrey, 1984.

[7] Camaret S., Rôle des perturbations dans la dynamique des pessières d'altitude. Impact des ouvertures artificielles et naturelles sur la régénération et le développement d'un peuplement forestier, Thèse, Université de Savoie, 1997.

[8] Coughenour M.B., Spatial components of plant-herbivore interactions in pastoral, ranching, and native ungulate ecosystems, J. Range Manage. 44 (1991) 530-542.

[9] Diaci J., Regeneration dynamics in a Norway spruce plantation on a silver fir-beech forest site in the Slovenian Alps, For. Ecol. Manage. 161 (2002) 127-138.

[10] Drexhage M., Colin F., Effects of browsing on shoots and roots of naturally regenerated sessile oak seedlings, Ann. For. Sci 60 (2003) 173-178.

[11] Edenius L., Danell K., Bergström R., Impact of herbivory and competition on compensatory growth in woody plants: winter browsing by moose on Scots pine, Oikos 66 (1993) 286-292.

[12] Eiberle K., Über den Einfluss des Wildverbisses auf die Mortalität von jungen Waldbäumen in der oberen Montanstufe, Schweiz. Z. Forstwes. 140 (1989) 1031-1042. 
[13] Eiberle K., Bucher H., Interdependenzen zwischen dem Verbiß verschiedener Baumarten in einem Plenterwaldgebiet, Z. Jagdwiss. 35 (1989) 235-244.

[14] Ellenberg H., Vegetation Ecology of Central Europe, Cambridge University Press, 1988.

[15] Gebert C., Verheyden-Tixier H., Variations of the diet of Red Deer (Cervus elaphus L.) in Europe, Mamm. Rev. 31 (2001) 189-201.

[16] Gill R.M.A., A review of damage by mammals in north temperate forests, 1. Deer, Forestry 65 (1992) 145-169.

[17] Gill RM.A., A review of damage by mammals in north temperate forests: 3. Impact on trees and forests, Forestry 65 (1992) 363-388.

[18] Gill R.M.A., Beardall V., The impact of deer on woodlands: the effects of browsing and seed dispersal on vegetation structure and composition, Forestry 74 (2001) 209-218.

[19] Grassi G., Bagnaresi U., Foliar morphological and physiological plasticity in Picea abies and Abies alba saplings along a natural light gradient, Tree Physiol. 21 (2001) 959-967.

[20] Guibert B., Maizeret C., Ballon P., Montes E., Influences of forest management on Roe deer populations in the Landes of Gascony, in: Proceedings of the International Symposium "Ongulés/Ungulates 91", Toulouse, France, September 2-6, 1991, 1992, pp. 617-620.

[21] Hobbs N.T., Modification of ecosystem by ungulates, J. Wildl. Manage. 60 (1996) 695-713.

[22] Holand O., Staaland H., Nutritional strategies and winter survival of European Roe deer in Norway, in: E. Bown (Ed.), Biology of Deer, Springer, NY, 1992, pp. 423-428.

[23] Hoskinson R.L., Mech D.L., White tailed deer migration and its role in wolf predation, J. Wildlife Manage. 43 (1976) 429-441, in: Okarma H. (Ed.), Le loup en Europe, Grands Espaces, 1998.

[24] Huntly N., Herbivores and the dynamics of communities and ecosystems, Annu. Rev. Ecol. Syst. 22 (1991) 477-503.

[25] Husson J.P., Les forêts du département des Vosges, 1820-1945, le temps des transformations décisives, Ann. Soc. Emulation des Vosges, 1988, pp. 85-94.

[26] Johnson A.S., Hale P.E., Ford W.M., Wentworth J.M., Frech J.R., Anderson O.F., Pullen G.B., White-tailed deer foraging in relation to successional stage, overstorey type and management of southern Appalachian forests, Am. Midl. Natl. 133 (1995) 18-35.

[27] Kay S., Factors affecting severity of deer browsing damage within coppiced woodlands in the south of England, Biol. Conserv. 63 (1993) 217-222.

[28] Kempf C., Baumgart G., Mammifères d'Alsace, Collection Patrimoine Naturel, Guides Gesta, Strasbourg, 1980.

[29] Klein F., Saint Andrieux C., Impact écologique des herbivores sur le sapin: éléments d'évaluation, in: Le sapin: enjeux anciens, enjeux actuels, L'Harmattan, Paris, 2001, pp. 71-88.

[30] Korpel S., Degree of equilibrium and dynamical changes of the forest on example of natural forests of Slovakia, Acta Facultatis Forestalis Zvolen XXIV (1982) 9-31.

[31] Lakière V., Normant P., Ballon P., Disponibilités alimentaires pour le chevreuil (Capreolus capreolus) dans deux sapinières régulière et jardinée du second plateau du Jura, Rev. For. Fr. 5 (2001) 511526.

[32] Legendre P., Legendre L., Numerical Ecology, Elsevier Science, B.V. Amsterdam, 1998.

[33] Louda S.M., Keeler K.H., Holt R.D., Herbivore influences on plant performance and competitive interactions, in: Grace J.B., Tilman D. (Eds.), Perspectives on Plant Competition, Academic Press, 1990, pp. 413-444.

[34] Lowe V.P.W., Observations on the dispersal of red deer on Rhum, Symp. Zool. Soc. Lond. 18 (1966) 211-228.

[35] Lyon L.J., Jensen C.E., Management implications of elk and deer use of clear-cuts in Montana, J. Wildl. Manage. 44 (1980) 352-362.

[36] Maillard D., Impact des cervidés sur la régénération naturelle du Sapin pectiné (Abies alba) dans les Vosges du Nord - bilan d'une première année d'expérimentation, ONC, Bull. Mens. 141 (1989) 14-17.

[37] Mayer H., Neumann M., Struktureller und entwicklungsdynamisher Vergleich der Fichten-Tannen-Buchen Urwälder Rothwald
Niederösterreich und Corkova Urwald, Kroatien. Forstw. Cbl. 100 (1981) 111-132.

[38] McLaren B.E., Plant specific response to herbivory: simulated browsing of suppressed balsam fir on Isle Royale, Ecology 77 (1996) 228-235.

[39] Oberdorfer E., Süddeutsche Pflanzengesellschaften, Pflanzensoziologie 10 (1957) 1-564.

[40] Picard J.F., Ballon P., Colin G., Frochot H., Incidence des populations de cervidés sur la régénération du sapin dans les Vosges, Rev. For. Fr. XLVI (1994) 137-150.

[41] Proudhon P., Guibert G., Klein F., Demolis C., Rôles et fonctions des différents types de peuplements forestiers en période hivernale vis-à-vis des grands cervidés. Cas du massif forestier d'Is-sur-Tille, Rev. For. Fr. XLVII (1995) 137-150.

[42] Putman R.J., Effects of grazing and browsing by mammals on woodlands, British Wildlife 5 (1994) 205-213.

[43] Rameau J.C., Aménagement forestier, importance de l'écologie, prise en compte de la biodiversité, Rev. For. Fr. Nº spécial (1999) 87-100.

[44] Reimoser F., Gossow H., Impact of ungulates on forest vegetation and its dependence on the sylvicultural system, For. Ecol. Manage. 88 (1996) 107-119.

[45] Ripley B.D., Pattern Recognition and Neural Networks, Cambridge University Press, 1996.

[46] Roguet C., Dumont B., Prache S., Selection and use of feeding sites and feeding stations by herbivores: A review, Ann. Zootech. 47 (1998) 225-244.

[47] Rolland C., Fonctionnement hydrique et croissance du sapin (Abies alba) dans les Alpes françaises. Dynamique des flux de sève, écophysiologie et dendroécologie, Thèses, Grenoble 1, 1993.

[48] Saint-Andrieux C., Wilmart D., Bernard S., Impacts respectifs du cerf et du chevreuil sur la régénération naturelle du sapin pectiné, Bull. Off. Nat. Chasse 247 (1999) 12-21.

[49] Schmidt K., Winter ecology of nonmigratory Alpine red deer, Oecologia 95 (1993) 226-233.

[50] Schweingruber F.H., Müller M., Dendrochronological evidence in fir and spruce of alternating frosts in Switzerland, Dendrochronologia 10 (1992) 23-28.

[51] Singer F.J., Hobbs T.N., Wang G., Evidence for the population limitation and alteration in distributions of elk following the reintroduction of wolves into Yellowstone National Park, US, Oral communication, International Conference on Forest Dynamics and Ungulate Herbivory, Davos, Switzerland, October 2001.

[52] Spiecker H., Silvicultural management in maintaining biodiversity and resistance of forests in Europe-temperate zone, J. Environ. Manage. 67 (2003) 55-65.

[53] Spitz F., Le jeu de rôle des dégâts de gibier, Courr. Environ. 33 (1998) 83-88.

[54] Staines B.W., The use of natural shelter by Red Deer (Cervus elaphus) in relation to weather in North-east Scotland, J. Zool. 180 (1976) $1-8$

[55] Staines B.W., Factors affecting the seasonal distribution of red deer (Cervus elaphus) at Glen Dye, North-east Scotland, Ann. Appl. Biol. 87 (1977) 495-512.

[56] Tan B.S., Étude de l'influence de quelques facteurs écologiques sur les premiers stades de la régénération du sapin (Abies alba) à l'étage montagnard du Jura, Rev. Ecol. Biol. Sol 24 (1987) 623635.

[57] Tan B.S., La régénération du sapin (Abies alba Mill.) dans le Jura : influence des facteurs physiques, édaphiques et biotiques sur les stades précoces du développement des semis, Thèse, Université de Franche-Comté, 1988.

[58] Vila B., Keller T., Guibal F., Influence of browsing cessation on Picea sitchensis radial growth, Ann. For. Sci 58 (2001) 853-859.

[59] Welch D., Staines B.W., Scott D., French D.D., Catt D.C., Leader browsing by red and roe deer on young sitka spruce trees in western Scotland. I. Damage rates and the influence of habitat factors, Forestry 64 (1991) 61-82. 